\title{
The Active Compound of Bangle Essential Oil as Cyclooxygenase-2 (Cox-2) Inhibitor: In Silico Approach
}

\author{
Richa Mardianingrum $^{1}{ }^{*}$, Gina Septiani Agustien ${ }^{1}$, Aas Nuraisah ${ }^{1}$, Ruswanto $^{2}$ \\ ${ }^{1}$ Department of Pharmacy, Perjuangan University, Tasikmalaya, Indonesia \\ ${ }^{2}$ Department of Pharmacy, Sekolah Tinggi Ilmu Kesehatan Bakti Tunas Husada, Tasikmalaya, Indonesia \\ *Corresponding author: richamardianingrum@unper.ac.id
}

Received: August 2020; Revision: October 2020; Accepted: December 2020; Available online: January 2021

\begin{abstract}
Fever is a condition where the body temperature rises above normal or more than $37^{\circ} \mathrm{C}$ and also tend to be an initial clinical manifestation of the use of antipyretic drugs that cause toxicity such as on the liver due to prolonged usage. Particularly, the bangle (Zingiber purpureum Roxb.) is one of the Zingiberaceae plants that contain essential oils used for the treatment of fever. Therefore, this research aimed to identify active compounds which have antipyretics potential with the in silico approach. The simulation of molecular docking showed 1,4naphthalenedione-2-ethyl-3-hydroxy was able to attach to the binding site of cyclooxygenase-2 (COX-2) and interact with main residues that constituted the active cavity of COX-2. While the simulation of molecular dynamics suggested that the bound compound was stable at $4 \mathrm{~ns}$, that is the time taken. The binding free energies expected by the MM-PBSA method indicated the 1,4-naphthalenedione-2-ethyl-3-hydroxy had a higher affinity than a native ligand (2-[(2,6-dichloro-3-methyl-phenyl)-amino] benzoic acid, JMS) and paracetamol. This suggested its capacity for advancing as a new COX-2 inhibitor.
\end{abstract}

Keywords: 1,4-naphthalenedione-2-ethyl-3-hydroxy, COX-2 inhibitor, bangle, molecular docking, molecular dynamics.

DOI: https://doi.org/10.15408/jkv.v6i2.16943

\section{INTRODUCTION}

Fever is generally a symptom, not a separate disease which indicates a reaction from the body to an infection that is characterized by an increase in body temperature above the normal $36-37{ }^{\circ} \mathrm{C}$ (Syamsi et al., 2019). The relief medication taken sometimes is a synthetic antipyretic which holds the risk of toxicity with extended usage. Therefore, patients prefer to use natural medicinal products with much effectiveness and comparatively low toxicity. Some plants contain bioactive compounds which include essential oil with medicinal properties.

Essential oil is a secondary metabolite compound produced by plants that have a distinctive odor or aroma. They have several activities, including antipyretics (Gunawan and Mulyani, 2002), anticancer (Bayala et al., 2014), antimicrobials (Bassolé \& Juliani, 2012), anti-inflammatory and antioxidant (Liju et al., 2011). One of the plants containing essential oils is bangle (Zingiber purpureum Roxb.) which consists of sabinene $(48.1 \%)$, terpinen-4-ol (25.1\%), c-terpinene $(6.7 \%), \alpha$ terpinene $(4.3 \%), \beta$-thujene $(3.4 \%)$, and $\alpha$ phellandrene (2.7\%) (Wang et al., 2015). Based on previous research, bangle rhizome essential oil doses 250, 500 and $1000 \mathrm{mg} / \mathrm{kg}$ BB provided an antipyretic effect on male mice (Mus musculus) (Mardianingrum et al., 2019).

The determination of activity is also performed in silico other than in vivo and in vitro. The in-silico method is used to predict the computational ability of a compound that tends to have the potential to cause biological effects in the search for new drugs that include the design and interactions of the compound with its receptor. This was developed to reduce costs and minimize the time needed in the process of finding new structural-based drug candidates (Wadood et al., 2013). Interestingly, antipyretic activity with in silico 
method from the bangle rhizome essential oil has not been explored yet, hence further research is needed. The investigation of active compounds in this oil can be conducted using Gas Chromatography-Mass Spectrometry (GCMS) instrument. In addition, molecular docking and molecular dynamics with cyclooxygenase-2 receptors (COX-2) of the active compounds were performed to determine those expected to have antipyretic activity.

\section{MATERIALS AND METHODS}

The fresh bangle rhizomes were harvested from Karangnunggal, Tasikmalaya, West Java Province, Indonesia, in April 2019. The plant was identified (3516/11.CO2.2/PL/2019) and deposited at the Herbarium of the School of Life Sciences and Technology, Bandung. The essential oil obtained by hydrodistillation within $6 \mathrm{~h}$ was investigated by the GC-MS (Wang et al., 2015) QP 2010S Shimadzu. The operational conditions of the instrument were Rtx-5MS column, length $30 \mathrm{~m}$, ID $0.25 \mathrm{~mm}$, helium carrier gas, ionizing EI $70 \mathrm{Ev}$, column temperature of $50^{\circ} \mathrm{C}$, injection $300^{\circ} \mathrm{C}$, split injection mode, and pressure $13 \mathrm{kPa}$. Also, total flow $79.3 \mathrm{~mL} / \mathrm{min}$, column flow 0.55 $\mathrm{mL} / \mathrm{min}$, linear velocity $26.8 \mathrm{~cm} / \mathrm{sec}$, purge flow $3 \mathrm{~mL} / \mathrm{min}$, split ratio 139, Ion source $250^{\circ} \mathrm{C}$, and interface $300^{\circ} \mathrm{C}$. But, the identification of the constituent compounds was carried out using Library-Wiley 229, LIB (Sipahelut, 2019).
Furthermore, with the Prediction of Activity Spectra for Substances (PASS) server (http:/www.pharmaexpert.ru/passonline/), the compounds' biological activities were analyzed. Using the structure-activity relationship (SAR) method, predictions were made about the compounds (Filimonov et al., 2018; Parikesit et al., 2020; and Gondokesumo et al., 2020). In addition, the molecular docking and molecular dynamics were used to predict the compounds' interaction with COX2 receptor as an antipyretic activity. The ChemDraw Ultra 8.0, Marvin Sketch 5.2.5.1, Molegro Molecular Viewer, AutoDock Tools 1.5.6, Amber 16, Discovery Studio 2016, and PreADMET were used in this research. The hardware of the personal computer used had a Compaq Intel inside Pentium Dual-Core 2.20 GHz; 3GB RAM, 32-bit system type, and an Operating System: Windows ${ }^{\circledR} 7$ Ultimate.

\section{RESULTS AND DISCUSSION}

Based on the results of GC-MS analysis, 16 peaks were detected among which the highest three had a large index of similarity and abundance. They include sabinene and 3carene delta with an area of $17.61 \%$ (peak 3), terpineol-4 with $56.57 \%$ (peak 11) and 1,4naphthalenedione-2-ethyl-3-hydroxy;

naphthalene; 3H-indole, 2,3,3-trimethyl; and biphenylene with $13.43 \%$ (peak 15). Furthermore, the main component of bangle rhizome essential oil (Zingiber purpureum Roxb.) can be seen in Figure 1.

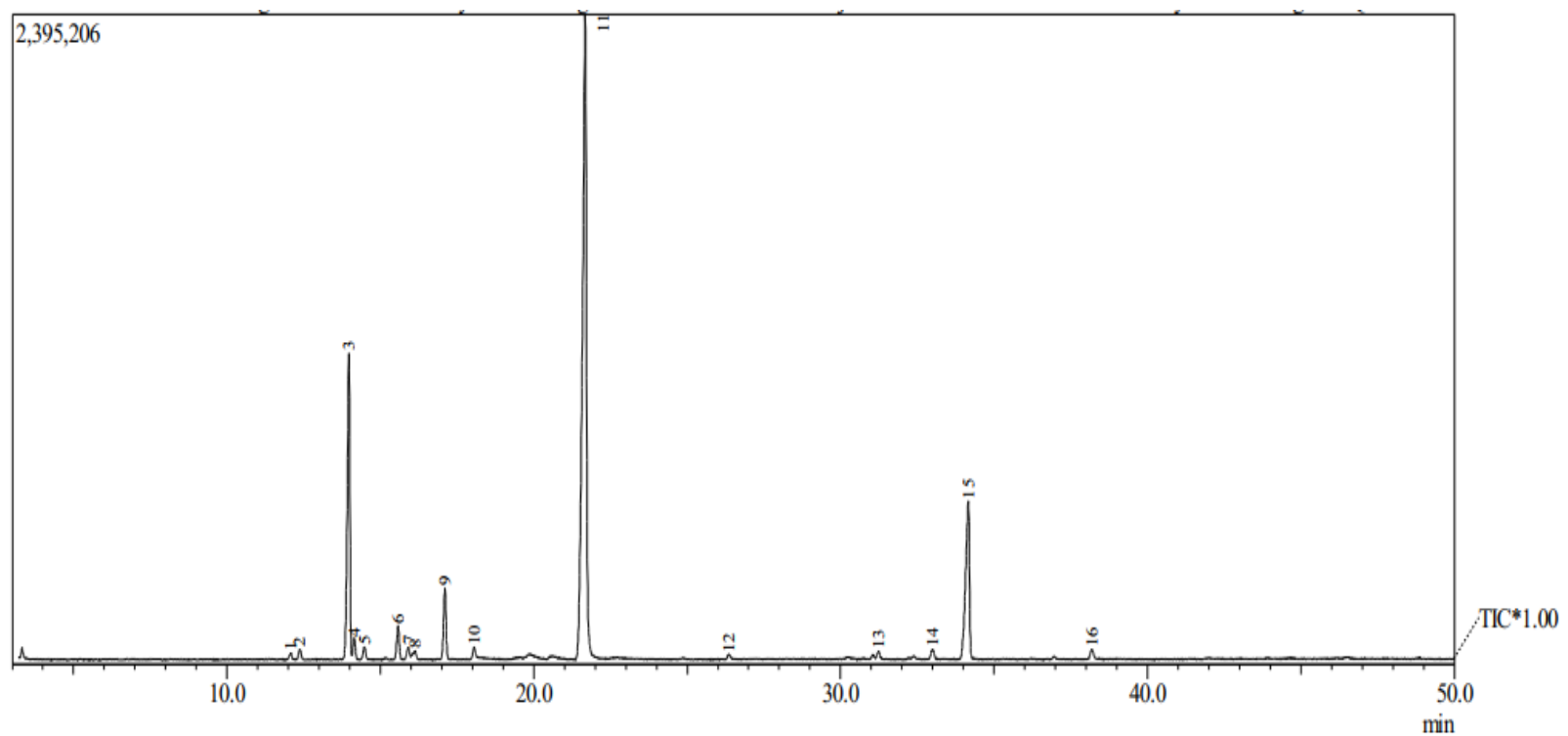

Figure 1. Chromatogram of Bangle Rhizome Essential Oil (Zingiber purpureum Roxb.) 
Table 1. The Chemical Compounds of Bangle Rhizome Essential Oil

\begin{tabular}{|c|c|c|c|c|c|c|}
\hline $\begin{array}{c}\text { No. } \\
\text { Peak }\end{array}$ & $\begin{array}{c}\text { Retention } \\
\text { time }\end{array}$ & $\begin{array}{c}\% \\
\text { Area }\end{array}$ & Formula & $\begin{array}{c}\text { Mol } \\
\text { Weight }\end{array}$ & Compound & Structure \\
\hline 1 & 12.067 & 0.32 & $\mathrm{C}_{10} \mathrm{H}_{16}$ & 136 & $\alpha$-Pinene & \\
\hline 2 & 12.067 & 0.32 & $\mathrm{C}_{10} \mathrm{H}_{16}$ & 136 & $\alpha$-Phellandrene & \\
\hline 3 & 12.067 & 0.32 & $\mathrm{C}_{10} \mathrm{H}_{16}$ & 136 & $\alpha$-Thujene & \\
\hline 4 & 12.375 & 0.57 & $\mathrm{C}_{10} \mathrm{H}_{16}$ & 136 & $\begin{array}{l}\text { 1,3,6-Octatriene, } \\
\text { 3,7-dimethyl- }\end{array}$ & \\
\hline 5 & 13.975 & 17.61 & $\mathrm{C}_{10} \mathrm{H}_{16}$ & 136 & Sabinene & \\
\hline 6 & 13.975 & 17.61 & $\mathrm{C}_{10} \mathrm{H}_{16}$ & 136 & $\delta$-3-Carene & \\
\hline 7 & 14.150 & 1.07 & $\mathrm{C}_{10} \mathrm{H}_{16}$ & 136 & $\beta$-Pinene & \\
\hline 8 & 14.475 & 0.66 & $\mathrm{C}_{10} \mathrm{H}_{16}$ & 136 & Myrcene & \\
\hline 9 & 15.575 & 1.75 & $\mathrm{C}_{10} \mathrm{H}_{16}$ & 136 & a.-Terpinene & \\
\hline 10 & 15.575 & 1.75 & $\mathrm{C}_{10} \mathrm{H}_{16}$ & 136 & $\alpha$-terpinolene & \\
\hline 11 & 15.575 & 1.75 & $\mathrm{C}_{10} \mathrm{H}_{16}$ & 136 & $\delta$-4-Carene & \\
\hline 12 & 15.917 & 0.70 & $\mathrm{C}_{10} \mathrm{H}_{14}$ & 134 & P-Cimene & \\
\hline 13 & 15.917 & 0.70 & $\mathrm{C}_{10} \mathrm{H}_{14}$ & 134 & $\begin{array}{l}\text { Benzene, 1-methyl- } \\
\text { 2-(1-methylethyl)- }\end{array}$ & \\
\hline 14 & 15.917 & 0.70 & $\mathrm{C}_{10} \mathrm{H}_{14}$ & 134 & $\begin{array}{l}\text { Benzene, 1-methyl- } \\
\text { 3-(1-methylethyl)- }\end{array}$ & \\
\hline 15 & 16.125 & 0.65 & $\mathrm{C}_{10} \mathrm{H}_{16}$ & 136 & Ocimene & \\
\hline 16 & 17.108 & 3.89 & $\mathrm{C}_{10} \mathrm{H}_{16}$ & 136 & $\gamma$-Terpinene & \\
\hline 17 & 18.050 & 0.67 & $\mathrm{C}_{10} \mathrm{H}_{16}$ & 136 & $\begin{array}{c}\text { 3-Octen-5-yne, 2,7- } \\
\text { dimethyl }\end{array}$ & \\
\hline 18 & 21.675 & 56.57 & $\mathrm{C}_{10} \mathrm{H}_{18} \mathrm{O}$ & 154 & Terpineol-4 & \\
\hline 19 & 26.350 & 0.37 & $\mathrm{C}_{12} \mathrm{H}_{20} \mathrm{O}_{2}$ & 196 & $\alpha$-Terpinyl acetate & \\
\hline
\end{tabular}




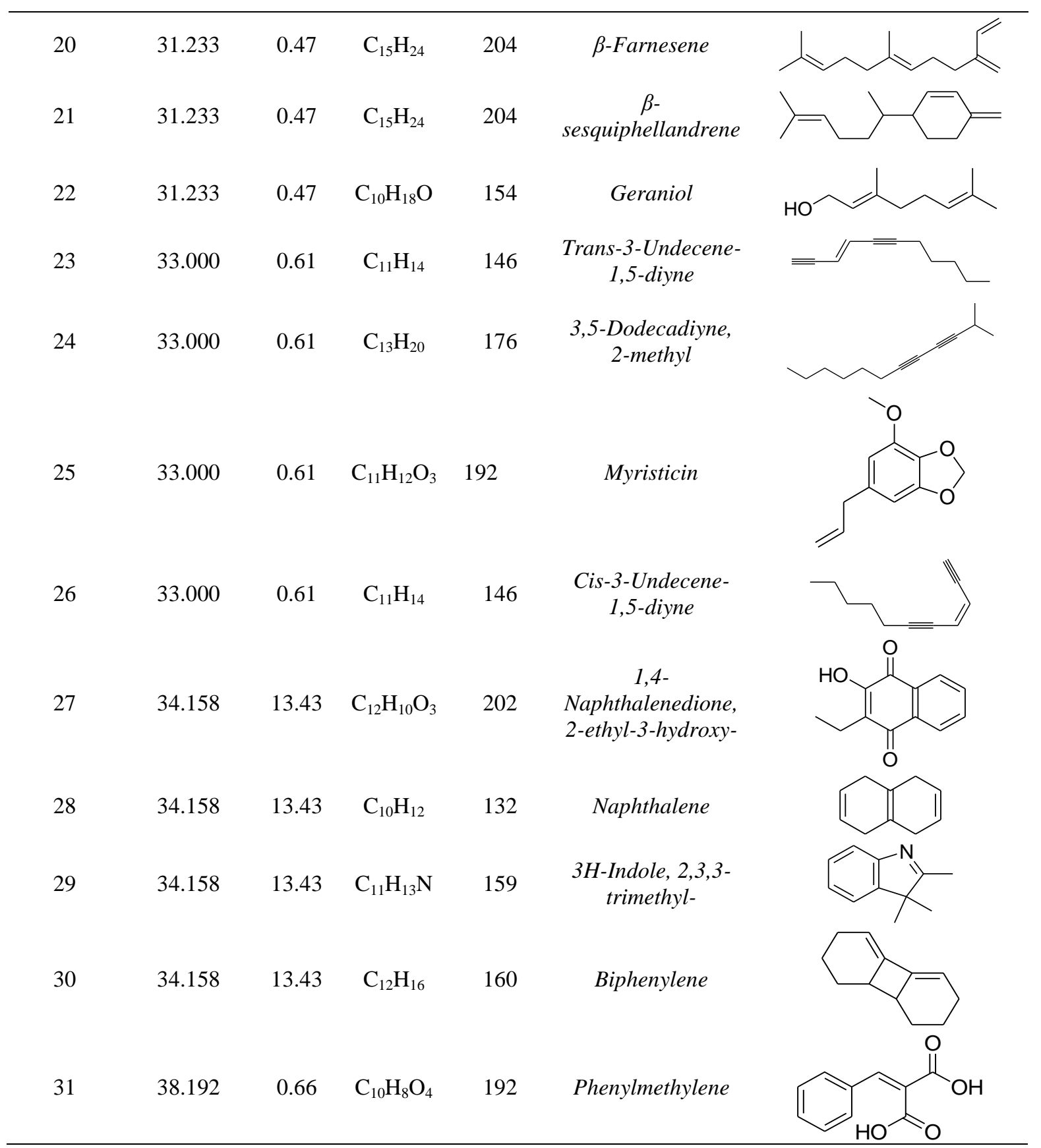

Table 1 shows the distribution of a total of essential oils, which were tested for the Pharmacokinetics and Lipinski's Rule of Five. The prediction of the compounds' pharmacokinetics and toxicity was performed using a web-based program (https://preadmet.bmdrc.kr/). The parameters of ADME (absorption, distribution, metabolism and excretion) used the Caco-2 value, HIA (Human Intestinal Absorption), and Plasma Protein Binding. Furthermore, the Caco-2 value was used to determine the permeability of the research samples, HIA was used to predict the percentage absorption of drugs in the human intestine, and the percentage of bound drugs was determined with Plasma Binding Protein. 
Table 2. The Results of Pharmacokinetic Aspects and Toxicity Prediction

\begin{tabular}{|c|c|c|c|c|c|c|c|}
\hline \multirow[b]{2}{*}{ No } & \multirow[b]{2}{*}{ Compound } & \multicolumn{3}{|c|}{ Pharmacokinetic Prediction } & \multicolumn{3}{|c|}{ Toxicity } \\
\hline & & Caco2 & HIA & PPB & Ames test & $\begin{array}{c}\text { Carcino } \\
\text { mouse }\end{array}$ & $\begin{array}{c}\text { Carcino } \\
\text { rat }\end{array}$ \\
\hline 1 & $\alpha$-Pinene & $23.63^{b}$ & $100.00^{c}$ & $100.00^{\mathrm{a}}$ & Mutagen & - & + \\
\hline 2 & $\alpha$-Phellandrene & $23.42^{b}$ & $100.00^{\mathrm{c}}$ & $100.00^{\mathrm{a}}$ & Mutagen & + & + \\
\hline 3 & $\alpha$-Thujene & $23.63^{b}$ & $100.00^{\mathrm{c}}$ & $100.00^{\mathrm{a}}$ & Mutagen & - & + \\
\hline 4 & $\begin{array}{l}\text { 1,3,6-Octatriene, 3,7- } \\
\text { dimethyl- }\end{array}$ & $23.63^{b}$ & $100.00^{c}$ & $100.00^{\mathrm{a}}$ & Mutagen & + & + \\
\hline 5 & Sabinene & $23.49^{b}$ & $100.00^{\mathrm{c}}$ & $60.97^{\mathrm{b}}$ & Mutagen & - & + \\
\hline 6 & $\delta$-3-Carene & $23.63^{b}$ & $100.00^{c}$ & $100.00^{\mathrm{a}}$ & Mutagen & - & + \\
\hline 7 & $\beta$-Pinene & $23.49^{b}$ & $100.00^{c}$ & $100.00^{\mathrm{a}}$ & Mutagen & - & + \\
\hline 8 & Myrcene & $23.63^{b}$ & $100.00^{\mathrm{c}}$ & $100.00^{\mathrm{a}}$ & Mutagen & - & + \\
\hline 9 & $\alpha$-Terpinene & $23.45^{b}$ & $100.00^{c}$ & $100.00^{\mathrm{a}}$ & Mutagen & + & + \\
\hline 10 & $\alpha$-terpinolene & $23.64^{b}$ & $100.00^{c}$ & $93.16^{\mathrm{a}}$ & Mutagen & + & + \\
\hline 11 & $\delta$-4-Carene & $23.63^{b}$ & $100.00^{c}$ & $100.00^{\mathrm{a}}$ & Mutagen & - & + \\
\hline 12 & P-Cimene & $23.43^{b}$ & $100.00^{c}$ & $100.00^{\mathrm{a}}$ & Mutagen & + & - \\
\hline 13 & $\begin{array}{c}\text { Benzene, } 1-\text { methyl-2-(1- } \\
\text { methylethyl)- }\end{array}$ & $23.43^{b}$ & $100.00^{\mathrm{c}}$ & $88.39^{b}$ & Mutagen & + & - \\
\hline 14 & $\begin{array}{c}\text { Benzene, 1-methyl-3-(1- } \\
\text { methylethyl)- }\end{array}$ & $23.46^{b}$ & $100.00^{c}$ & $100.00^{\mathrm{a}}$ & Mutagen & - & - \\
\hline 15 & Ocimene & $23.49^{b}$ & $100.00^{\mathrm{c}}$ & $100.00^{\mathrm{a}}$ & Mutagen & + & + \\
\hline 16 & $\gamma$-Terpinene & $23.64^{b}$ & $100.00^{\mathrm{c}}$ & $100.00^{\mathrm{a}}$ & Mutagen & + & + \\
\hline 17 & $\begin{array}{l}\text { 3-Octen-5-yne, 2,7- } \\
\text { dimethyl }\end{array}$ & $23.59^{b}$ & $100.00^{\mathrm{c}}$ & $100.00^{\mathrm{a}}$ & Mutagen & + & + \\
\hline 18 & Terpineol-4 & $50.81^{b}$ & $100.00^{\mathrm{c}}$ & $100.00^{\mathrm{a}}$ & Mutagen & + & - \\
\hline 19 & $\alpha$-Terpinyl acetate & $37.76^{b}$ & $100.00^{c}$ & $98.54^{\mathrm{a}}$ & Mutagen & - & - \\
\hline 20 & $\beta$-Farnesene & $23.40^{\mathrm{b}}$ & $100.00^{c}$ & $100.00^{\mathrm{a}}$ & Non-Mutagen & + & + \\
\hline 21 & $\beta$-sesqui phellandrene & $23.40^{\mathrm{b}}$ & $100.00^{c}$ & $100.00^{\mathrm{a}}$ & Mutagen & + & + \\
\hline 22 & Geraniol & $8.75^{b}$ & $100.00^{\mathrm{c}}$ & $100.00^{\mathrm{a}}$ & Mutagen & + & - \\
\hline 23 & $\begin{array}{c}\text { Trans-3-Undecene-1,5- } \\
\text { diyne }\end{array}$ & $24.03^{b}$ & $100.00^{c}$ & $100.00^{\mathrm{a}}$ & Mutagen & + & + \\
\hline 24 & $\begin{array}{l}\text { 3,5-Dodecadiyne, } 2- \\
\text { methyl }\end{array}$ & $22.54^{b}$ & $100.00^{\mathrm{c}}$ & $100.00^{\mathrm{a}}$ & Mutagen & + & + \\
\hline 25 & Myristicin & $57.43^{b}$ & $100.00^{c}$ & $96.98^{\mathrm{a}}$ & Mutagen & + & + \\
\hline 26 & $\begin{array}{l}\text { Cis-3-Undecene-1,5- } \\
\text { diyne }\end{array}$ & $24.03^{b}$ & $100.00^{\mathrm{c}}$ & $100.00^{\mathrm{a}}$ & Mutagen & + & + \\
\hline 27 & $\begin{array}{l}\text { 1,4-Naphtha lenedione, } \\
\text { 2-ethyl-3-hydroxy- }\end{array}$ & $20.14^{b}$ & $94.85^{c}$ & $86.71^{\mathrm{b}}$ & Mutagen & + & + \\
\hline 28 & Naphthalene & $23.41^{\mathrm{b}}$ & $100.00^{\mathrm{c}}$ & $100.00^{\mathrm{a}}$ & Mutagen & + & + \\
\hline 29 & $\begin{array}{l}\text { 3H-Indole, } 2,3,3- \\
\text { trimethyl- }\end{array}$ & $35.94^{b}$ & $100.00^{c}$ & $44.57^{\mathrm{b}}$ & Mutagen & - & + \\
\hline 30 & Biphenylene & $23.40^{b}$ & $100.00^{\mathrm{c}}$ & $100.00^{\mathrm{a}}$ & Mutagen & + & + \\
\hline 31 & Phenylmethylene & $20.74^{b}$ & $88.16^{\mathrm{c}}$ & $79.62^{b}$ & Mutagen & - & + \\
\hline 32 & Paracetamol & $18.78^{b}$ & $88.23^{c}$ & $0.00^{\mathrm{b}}$ & Mutagen & - & + \\
\hline
\end{tabular}

Note: Caco-2 (<4 Low ${ }^{\mathrm{a}} ; 4$ - 70 Medium $\left.{ }^{\mathrm{b}} ;>70 \mathrm{High}^{\mathrm{c}}\right)$

HIA (0 - 20\% Poor $^{\text {a }} ; 20-70 \%$ Medium $^{\mathrm{b}} ; 70-100 \% \operatorname{Good}^{\mathrm{c}}$ )

PPB ( $>90 \%$ Strong Bound ${ }^{\mathrm{a}} ;<90 \%$ Weakly Bound $^{\mathrm{b}}$ ). 
Based on Table 2, the positive control (paracetamol) and all compounds of bangle rhizome essential oils were predicted to have a moderate permeability value of 4-70. The percentage of absorption in the human intestine fell into a good range of 70-100\%, and that of blood proteins' binding was $>90 \%$ which shows strong bonds with plasma proteins. But, the paracetamol, sabinene; benzene 1-methyl3- (1-methyl ethyl); 1,4-naphthalenedione-2ethyl-3-hydroxy; 3H-indole,2,3,3-trimethyl; and phenyl methylene had a low percentage of protein binding of blood which was $<90 \%$, namely $88.25 \%, 0 \%, 60.97 \%, 88.39 \%$, $86.71 \%, 44.57 \%$ and $79.62 \%$ for each. This showed a weak bond with plasma protein in the sense of being able to distribute well, which is consistent with the hypothesis that plasma-bound drugs are inert. And that, only free and unregulated drugs are able to operate on targets to create a biological reaction, as well as join the removal phase (Harvey et al., 2013).

According to the pharmacokinetic results, the sabinene selected compounds namely benzene, 1-methyl-3- (1-methyl-ethyl), 1,4-naphthalenedione-2-ethyl-3-hydroxy, 3Hindole-2,3,3-trimethyl and phenyl methylene were screened based on the Lipinski's Rule of Five predictions. Furthermore, Drug Likeness refers to the oral administration of drugs related to the process of their absorption and distribution. The criteria for a good drug need to follow Lipinski's rule of five which states molecular weight $<500 \mathrm{~g} / \mathrm{mol}, \log \mathrm{P}<5$, hydrogen bond donor $<5$, hydrogen bond acceptor $<10$, and molar refractory between 40 - 130. The result data of Lipinski's rules can be seen in Table 3. Based on Table 3, the paracetamol, sabinene; benzene, 1-methyl-3- (1-methyl ethyl); 1,4-naphthalenedione-2ethyl-3-hydroxy; 3H-indole-2,3,3-trimethyl and phenyl methylene followed the Lipinski's rule of five criteria, therefore they can potentially be administered orally. Also, the molecular weight value was related to the drug distribution process that occurred by penetrating the biological membrane through diffusion. The compounds with molecular weights $>500 \mathrm{~g} / \mathrm{mol}$ tend to hardly penetrate biological membranes which causes a long absorption time for the drug. But, those with lower molecular weights penetrate more easily (Adriani, 2018).

The $\log \mathrm{P}$ value is related to the hydrophobicity or lipophilicity of a compound. The greater it is, the higher the hydrophobic property becomes. Therefore, when it is $>5$, a compound stays longer in the lipid bilayer and is more widely distributed in the body. This causes the selectivity of bonds to target enzymes to be reduced and tends to have higher toxicity. The $\log \mathrm{P}$ value need not be negative, otherwise, the compound cannot pass through the lipid bilayer membrane and interaction with water solvents tends to occur (Kilo et al., 2019).

The amount of hydrogen bonds in the donor and acceptor correlates with the biological activity of a compound. Also, the binding capacity of the donor and acceptor is directly proportional to the energy needed for the absorption process to occur (Syahputra $e t$ al., 2014). In addition, the refractory molar is a total polarizability value of a drug molecule (Ruswanto, 2015), where a non-polar compound is able to form momentum to ensure it binds to the receptor. And, its polar properties function to facilitate excretion of the rest of the compound from the body.

Table 3. The results of Lipinski's rule of five

\begin{tabular}{|c|c|c|c|c|c|c|}
\hline \multirow{3}{*}{ No } & \multirow{3}{*}{ Compound } & \multicolumn{5}{|c|}{ Parameter } \\
\hline & & Mol Weight & $\begin{array}{l}\text { Proton } \\
\text { donors }\end{array}$ & $\begin{array}{c}\text { Proton } \\
\text { acceptor }\end{array}$ & $\log P$ & $\begin{array}{c}\text { Refractory } \\
\text { Molar }\end{array}$ \\
\hline & & $<500 \mathrm{~g} / \mathrm{mol}$ & $<5$ & $<10$ & $<5$ & $40-130$ \\
\hline 1 & Paracetamol & 151.06 & 2 & 3 & 0.28 & 42.90 \\
\hline 2 & Sabinene & 136.13 & 0 & 0 & 2.95 & 43.65 \\
\hline 3 & $\begin{array}{l}\text { Benzene, 1-methyl-3-(1- } \\
\text { methylethyl)- }\end{array}$ & 134.11 & 0 & 0 & 3.76 & 45.29 \\
\hline 4 & $\begin{array}{l}\text { 1,4-Naphthalenedione- 2-ethyl-3- } \\
\text { hydroxy- }\end{array}$ & 202.06 & 1 & 5 & 0.52 & 57.11 \\
\hline 5 & 3H-Indole- 2,3,3-trimethyl- & 159.1 & 0 & 1 & 2.74 & 52.68 \\
\hline 6 & Phenylmethylene & 192.04 & 2 & 6 & 1.35 & 49.13 \\
\hline
\end{tabular}




\section{The activity prediction of the compounds with PASS online server}

Table 4. The activity prediction by PASS online

\begin{tabular}{clccc}
\hline No. & \multicolumn{1}{c}{ Compound } & Pa & $\mathbf{P i}$ & Activity Prediction \\
\hline 1 & Sabinene & 0.199 & 0.097 & cyclooxygenase substrate \\
2 & Benzene, 1-methyl-3-(1-methylethyl)- & 0.527 & 0.010 & antipyretic \\
3 & 1,4-Naphthalenedione- 2-ethyl-3- & 0.370 & 0.030 & antipyretic \\
& hydroxy- & 0.185 & 0.130 & antipyretic \\
5 & 3H-Indole- 2,3,3-trimethyl- & 0.299 & 0.045 & antipyretic \\
\hline
\end{tabular}

To determine the activity prediction in antipyretic/cyclooxygenase inhibitor, an analysis was conducted with the Prediction of Activity Spectra for Substances (PASS) server (http:/www.pharmaexpert.ru/passonline/).

Also, there were predictions made using the method of structure-activity relationships (SAR). Similar activities have been considered for structurally related compounds with an active cluster. In a versatile way, it is possible to interpret and use the PASS predictions as follows, (i) Only activities with $\mathrm{Pa}>\mathrm{Pi}$ for a specific compound are known to be feasible. (ii) When $\mathrm{Pa}>0.7$, the ability to experimentally discover the behavior is high. However, the compound tends to be a near analog of recognized pharmaceutical agents in certain instances. (iii) There is also less possibility of experimentally discovering the operation, but the potential to find a structurally new compound, that is, NCEs, increases (Marwaha et. al, 2007). The activity prediction from the PASS online server is presented in Table 4. Based on Table 4, all compounds have $\mathrm{Pa}>\mathrm{Pi}$ which indicated that they possibly have antipyretic activity.

\section{Molecular Docking and Visualization of Interactions with Target Proteins}

Paracetamol is a branded antipyretic drug, selected as a comparative agent based on its mechanism of action, which prevents the development of prostaglandin by inhibiting COX-2 activity. The cyclooxygenase-2 (pdbID: 5IKQ) selected for molecular docking with the name of native ligand was 2-[(2,6dichloro-3-methyl-phenyl)-amino] benzoic acid (JMS).

The 5IKQ was validated with re-docking the JMS into the binding site. The results showed an an RMSD value of $0.60 \AA$ with a Grid box position $X=22,518, Y=51,524$, and
$\mathrm{Z}=17,635 \AA$, as well as a binding affinity value of $-8.31 \mathrm{kcal} / \mathrm{mol}$. The JMS overlay of the re-docking results can be seen in Figure 2.

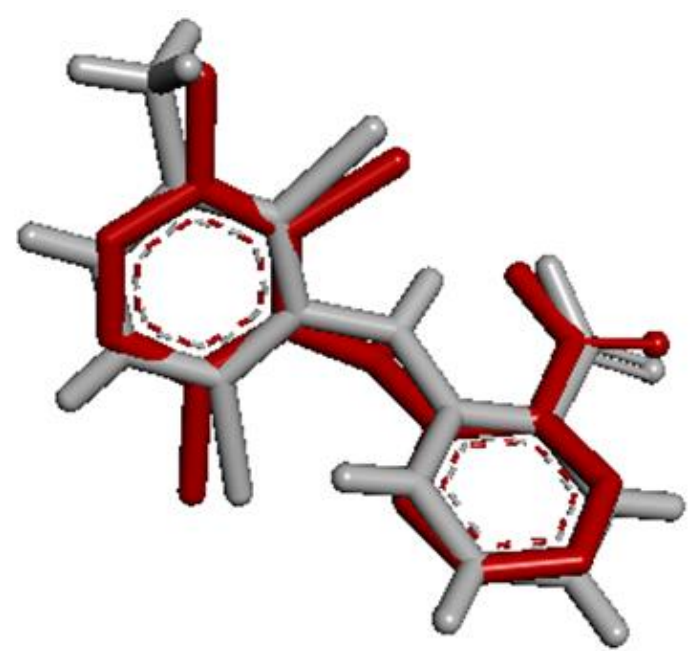

Figure 2. The JMS Overlay of re-docking result (red) with the crystallographic structure (white)

The molecular docking results of paracetamol and compounds of essential oils (rhizome bangle) against COX-2 are presented in the following Table 5. Based on the molecular docking results in Table 5, the native ligand (JMS) had a binding affinity $(\Delta \mathrm{G})$ smaller than active compounds of essential oil and paracetamol with $\Delta \mathrm{G}$ value of $-8.31 \mathrm{kcal} / \mathrm{mol}$ and $\mathrm{Ki}$ of $0.81 \mu \mathrm{M}$. The binding affinity of the paracetamol was $-5.23 \mathrm{kcal} / \mathrm{mol}$ with a value of $\mathrm{Ki} 146.67 \mu \mathrm{M}$. The $\Delta \mathrm{G}$ of the active compounds was smaller than that of the paracetamol. The lowest $\Delta \mathrm{G}$ of the active compounds (bangle rhizome essential oils) was found in the 1,4-Naphthalenedione-2-ethyl-3hydroxy $(\Delta \mathrm{G}=-7.31 \mathrm{kcal} / \mathrm{mol} ; \mathrm{Ki}=4.37 \mu \mathrm{M})$, which binds to COX-2 better than paracetamol. Meanwhile, its affinity is still not sufficient compared to the native ligand, JMS (-8.31 $\mathrm{kcal} / \mathrm{mol})$. 
Table 5. The Recapitulation of Molecular Docking Results

\begin{tabular}{|c|c|c|c|c|c|}
\hline \multirow[b]{2}{*}{ No } & \multirow[b]{2}{*}{ Compound } & \multirow{2}{*}{$\begin{array}{c}\Delta \mathbf{G} \\
\mathrm{kcal} / \mathrm{mol}\end{array}$} & \multirow{2}{*}{$\underset{(\mu \mathbf{M})}{\mathbf{K i}}$} & \multicolumn{2}{|c|}{ Interaction with Amino Acids } \\
\hline & & & & $\begin{array}{l}\text { Hydrogen } \\
\text { bonds }\end{array}$ & Hydrophobic Bonds \\
\hline 1 & JMS & -8.31 & 0.81 & $\begin{array}{l}\text { Ser530, } \\
\text { Tyr385 }\end{array}$ & $\begin{array}{l}\text { Met522, Gly526, Leu384, } \\
\text { Trp387, Phe381, Trp348, } \\
\text { Ser353, Tyr355, Arg120 }\end{array}$ \\
\hline 2 & Paracetamol & -5.23 & 146.67 & Met522 & $\begin{array}{c}\text { Gly526, Leu384, Phe381, } \\
\text { Tyr385, Ser530, Val344, } \\
\text { Val349, Tyr348, Leu352, } \\
\text { Phe518, Val523 }\end{array}$ \\
\hline 3 & Sabinene & -5.85 & 51.48 & & Ser530, Gly526 \\
\hline 4 & $\begin{array}{l}\text { Benzene, 1-methyl-3-(1- } \\
\text { methylethyl)- }\end{array}$ & -5.67 & 69.91 & & Ser530, Leu384, Trp387 \\
\hline 5 & $\begin{array}{l}\text { 1,4-Naphthalenedione, } 2- \\
\text { ethyl-3-hydroxy- }\end{array}$ & -7.31 & 4.37 & $\begin{array}{l}\text { Ser530, } \\
\text { Tyr385 }\end{array}$ & $\begin{array}{l}\text { Tyr348, Leu352, Phe381, } \\
\text { Trp387, Gly526, Val523 }\end{array}$ \\
\hline 6 & $\begin{array}{l}\text { 3H-Indole, } 2,3,3- \\
\text { trimethyl- }\end{array}$ & -6.31 & 23.73 & & $\begin{array}{c}\text { Leu384, Gly526, Val523, } \\
\text { Phe518, Ser353, Phe381, } \\
\text { Tyr385, Ser530 }\end{array}$ \\
\hline 7 & Phenylmethylene & -6.08 & 34.98 & $\begin{array}{l}\text { Tyr355, } \\
\text { Arg } 120\end{array}$ & $\begin{array}{l}\text { Leu359, Leu531, Val116, } \\
\text { Leu93 }\end{array}$ \\
\hline
\end{tabular}

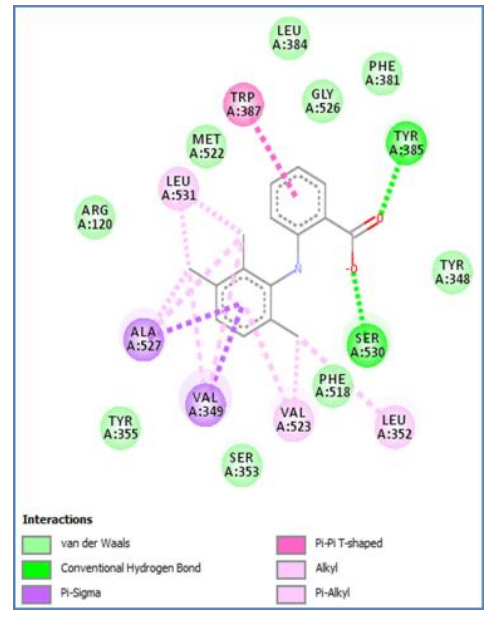

(a)

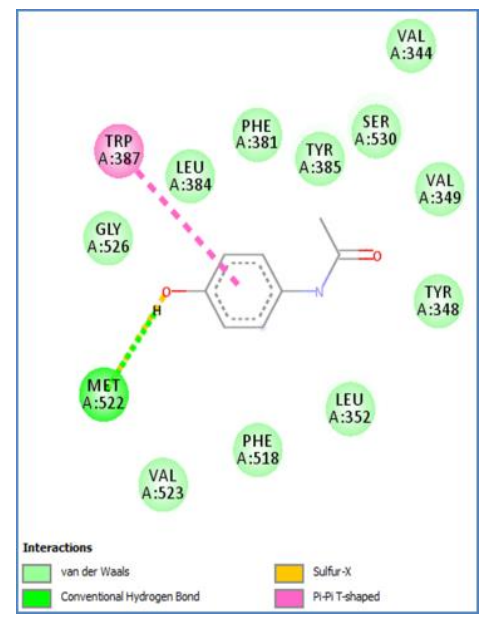

(b)

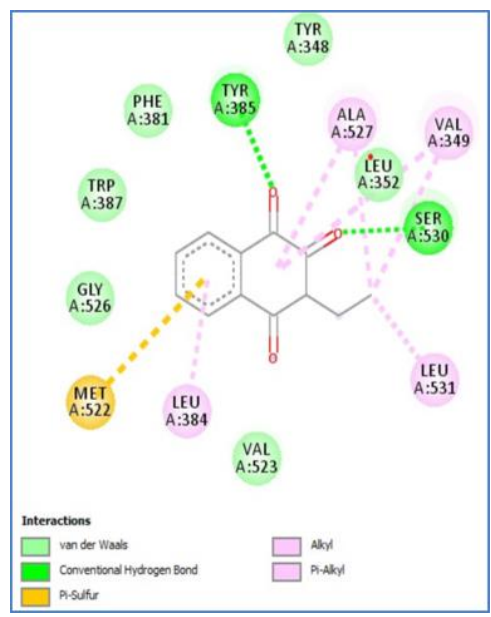

(c)

Figure 3. The 2D Visualization of molecular docking results: JMS (a), paracetamol (b), and 1,4Naphthalenedione-2-ethyl-3-hydroxy (c)

Figure 3 showed the similarity of hydrogen bonds that occurred in 1,4Naphthalenedione-2-ethyl-3-hydroxy and the native ligands (JMS), namely Ser530 and Tyr385. Predictably, the stability of the active compound will be the same as the JMS in COX-2 receptors. The 1,4-naphthalenedione-2ethyl-3-hydroxy is also similar to comparative drugs (paracetamol) namely in hydrophobic bonds including Tyr348, Leu352, Phe381, and Gly526. This similarity indicates the level of drug solubility in the cell membrane and it is predicted to be bound both to the receptor site and the drug.

\section{Molecular Dynamics Simulation}

Interaction occuring during docking were tested using molecular dynamics within 10 ns (10000ps) for calculating the Root Mean Square Deviation (RMSD) and Root Mean Square Fluctuation (RMSF). The RMSD was used to conformation during simulation process, and its values for the JMS compound, 1,4-naphtalenedione-2-ethyl-3-hydroxy, and paracetamol against COX-2 can be seen in figure 4. The JMS and 1,4-naphthalenedione2-ethyl-3-hydroxy complexes against COX-2 achieved stable conformation almost at the same time. Where, the system reached a 
generally stable condition after the simulation run at $2000 \mathrm{ps}$ (2ns), and the paracetamol began to stabilize at $4000 \mathrm{ps}(4 \mathrm{~ns})$. The highest RMSD was achieved by paracetamol with a value of $\pm 1.5 \AA$, while JMS $\pm 1.4 \AA$ and the lowest value was achieved by 1,4naphthalenedione-2-ethyl-3-hydroxy- which was $\pm 1.3 \AA$. Conclusively, the active compound is predicted to have a more stable interaction with COX-2 than the counterparts.

Unlike RMSD, the RMSF value represents the stability of residues of amino acids in large measure. Residues with low fluctuations suggest that they do not have high flexibility and are said to have stable interactions or bonds and they play an active role at the ligand-receptor binding site. While those with large fluctuations suggest that these residues are extremely versatile and also have interactions or unstable bonds leading to many changes during simulations. The RMSF of the three compounds against COX-2 is shown in Figure 5.

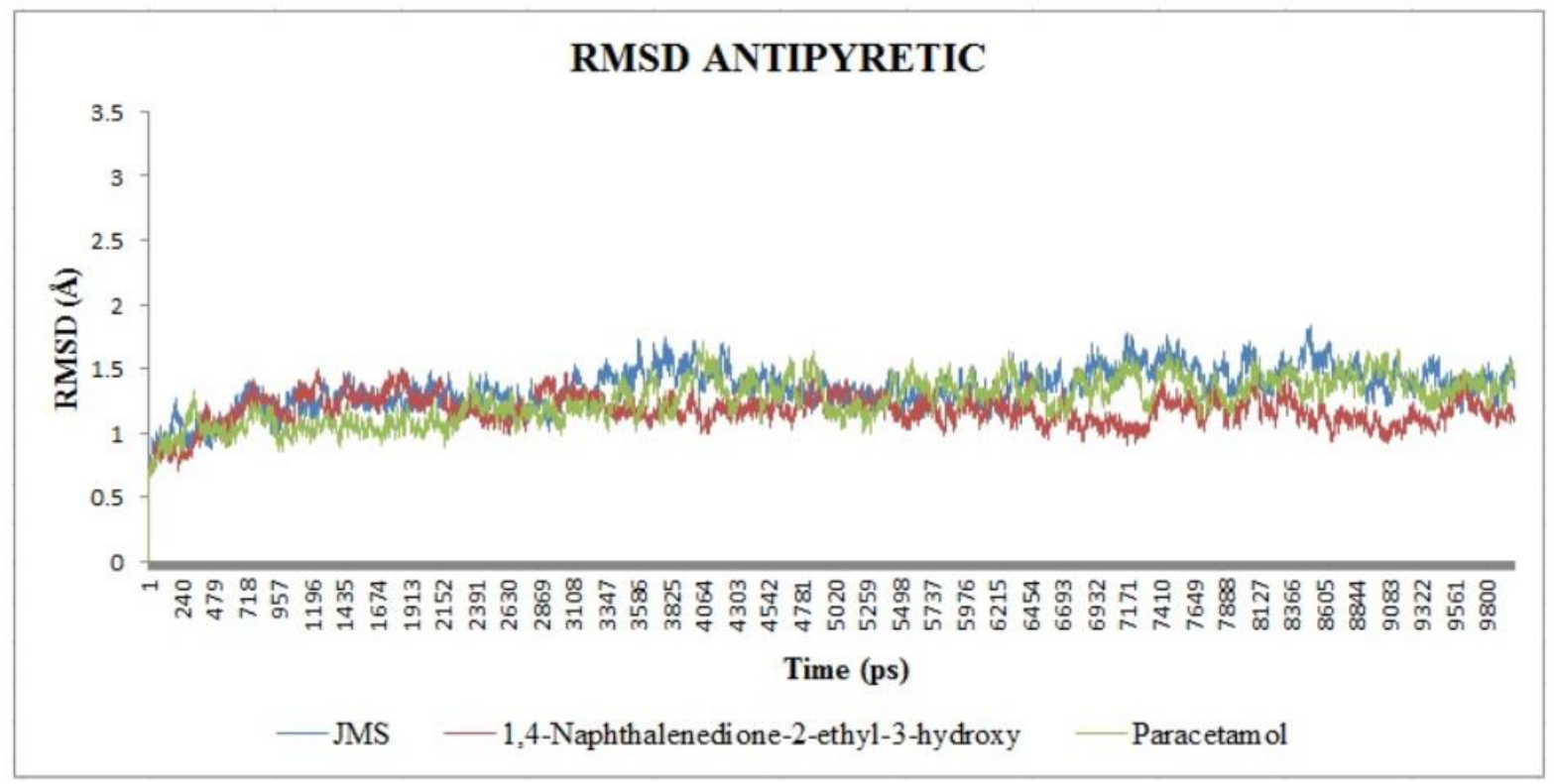

Figure 4. The RMSD curve of JMS, 1,4-Naphthalenedione-2-ethyl-3-hydroxy and Paracetamol to COX-2

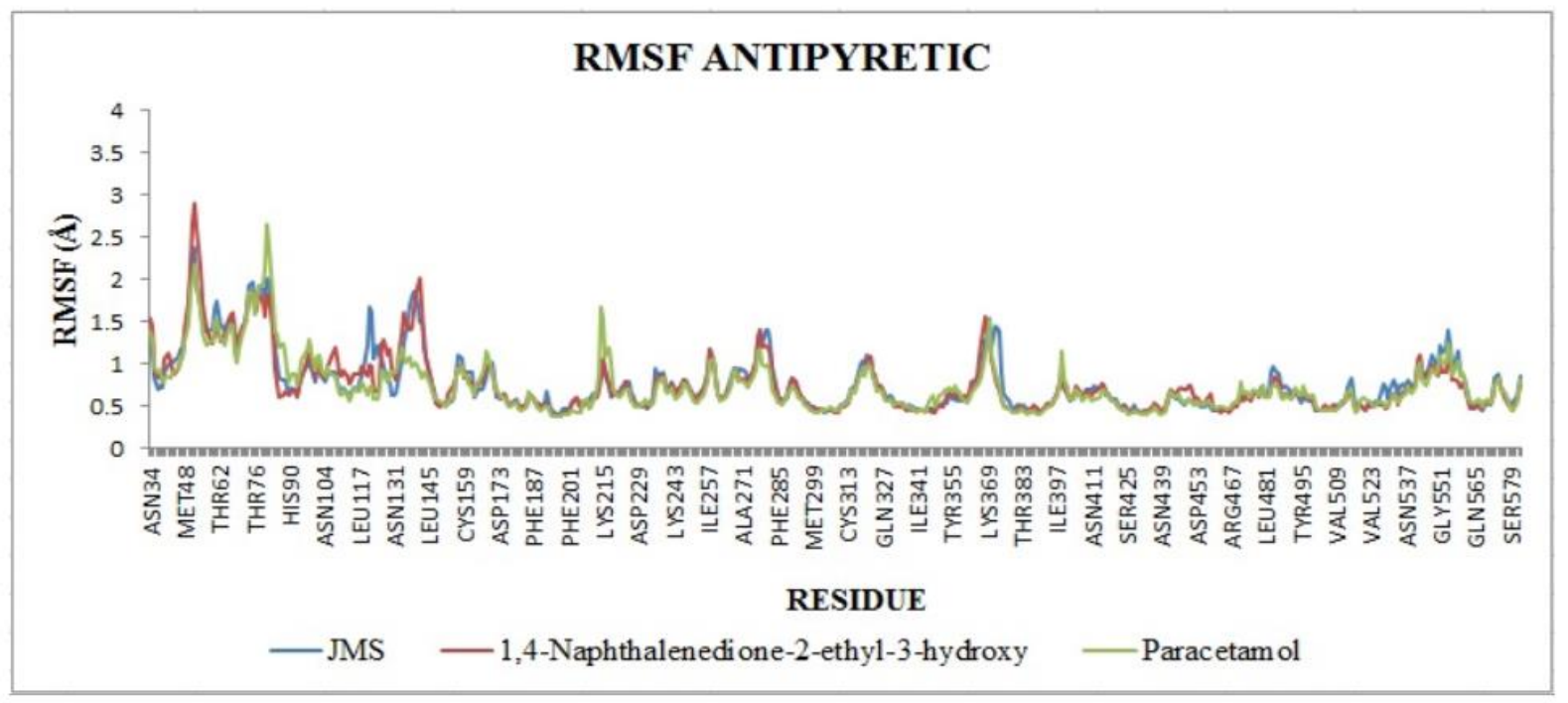

Figure 5. The RMSF curve of JMS system, 1,4-naphthalenedione-2-ethyl-3-hydroxy and paracetamol against $\mathrm{COX}-2$ 
Based on Figure 5, the residues with the highest fluctuations in JMS system were Phe52, Phe81, Ser121, Ser138 and Gln370. Furthermore, those in 1,4-Naphthalenedione-2ethyl-3-hydroxy were Phe52, Ala141, Gln278 and Asn368, and those in paracetamol were Gly51, Leu82, His214, Gln278, and Gln370. In conclusion, the highest fluctuations residues are Phe52, Phe81, His214 dan Gln370, therefore, they do not play an active role on the binding site.
The low fluctuations residues in JMS system were Met196, Met197, and Asn439, and those in 1,4-naphthalenedione-2-ethyl-3hydroxy and paracetamol were Met196, Met197 and Phe198. Based on RMSF data, they have low flexibility in each system, hence it was predicted that the three compounds interacted stably with COX-2. Here's a separate RMSF curve from that of JMS, 1,4naphthalenedione-2-ethyl-3-hydroxy, and paracetamol against COX-2 (figure 6, 7 and 8).

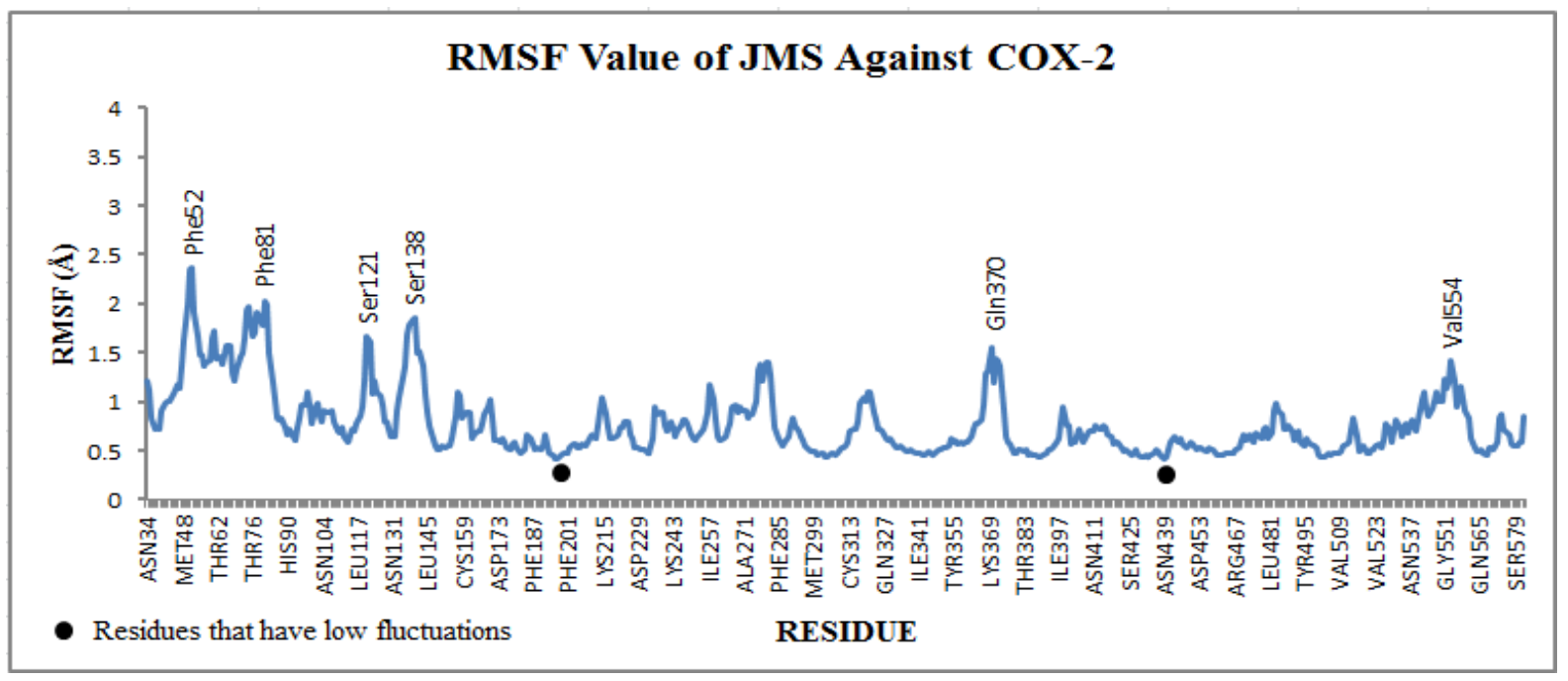

Figure 6. The RMSF curve of JMS-COX-2

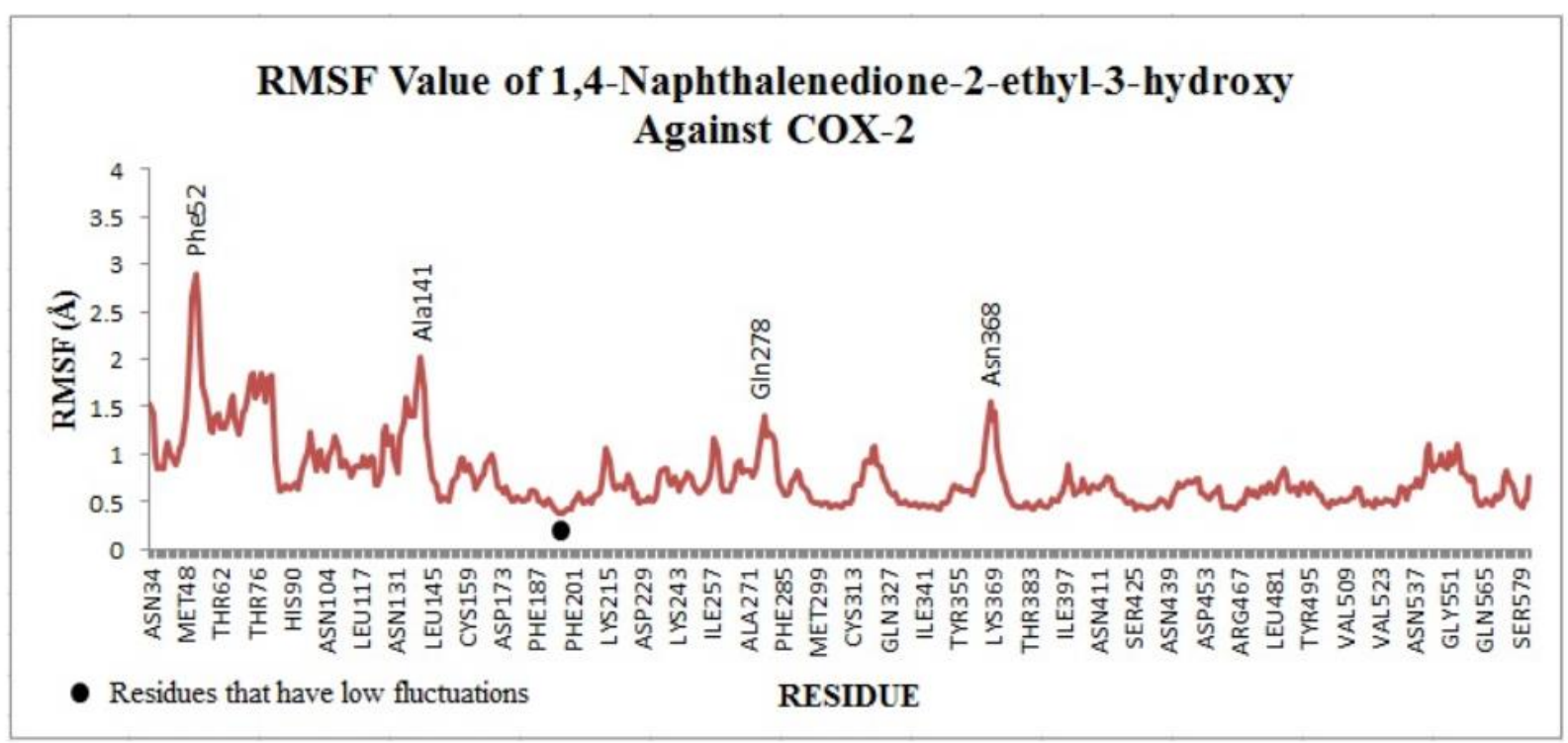

Figure 7. The RMSF curve of 1,4-naphthalenedione-2-ethyl-3-hydroxy-COX-2 


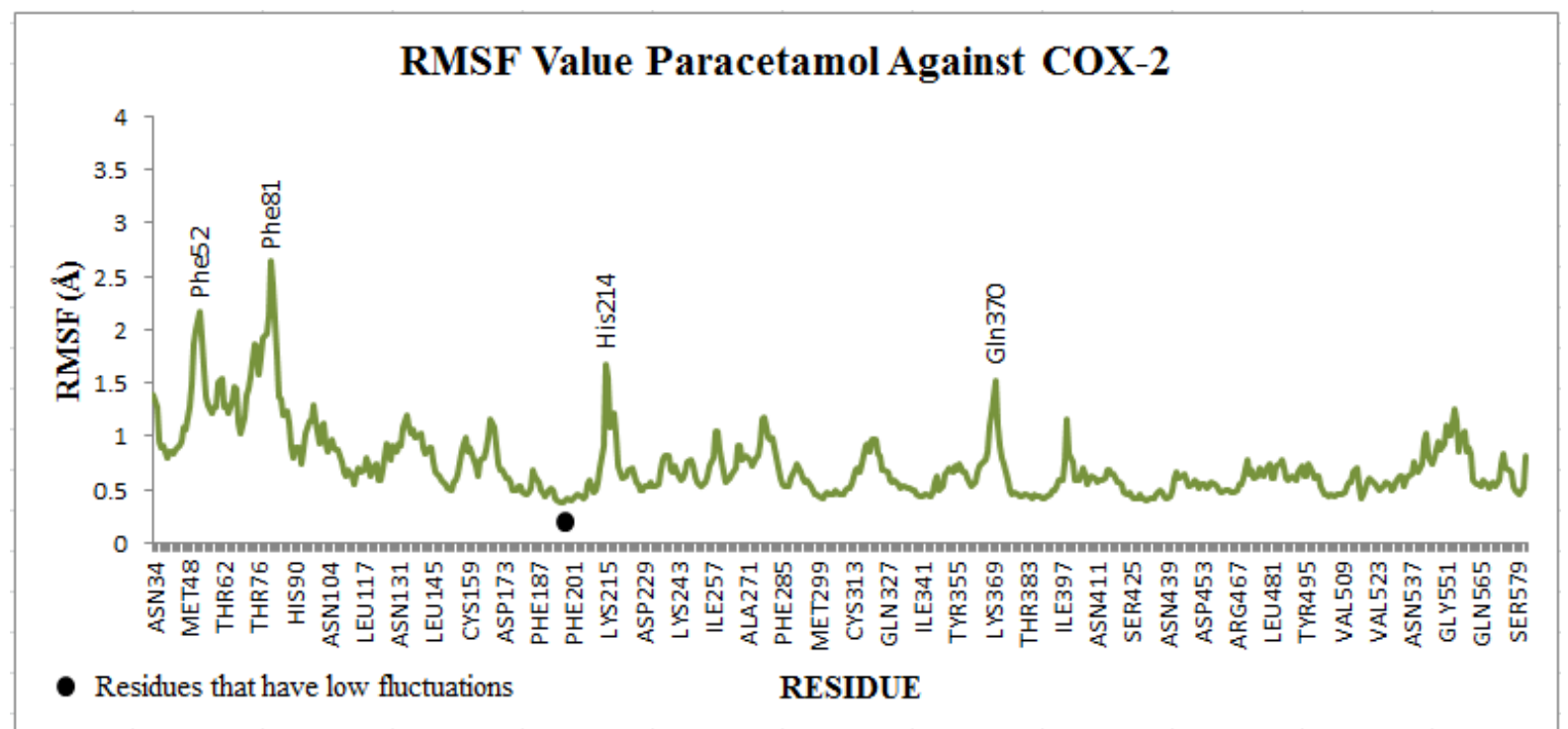

Figure 8. The RMSF curve of Paracetamol-COX-2

Table 5. The MM-BSA calculation results of JMS, 1,4-Naphthalenedione-2-ethyl-3-hydroxy and Paracetamol system

\begin{tabular}{ccccc}
\hline \multirow{2}{*}{ No } & Energy Component (kcal/mol) & \multicolumn{3}{c}{ System } \\
\cline { 3 - 5 } & & $\begin{array}{r}\text { JMS - } \\
\text { COX-2 }\end{array}$ & $\begin{array}{c}\text { 1,4-Naphthalenedione, 2-ethyl-PCT - COX } \\
\text { 3-hydroxy - COX-2 }\end{array}$ & $\mathbf{2}$ \\
\hline 1 & Van der Waals (VdW) & -43.64 & -25.91 & -25.91 \\
2 & Electrostatic Energy (EEL) & -24.79 & -194.45 & -65.82 \\
3 & Electrostatic Contribution to the solvation Free & 45.80 & 195.51 & 72.05 \\
& $\quad$ Energy (EGB) & & -3.68 & -3.48 \\
4 & Non-polar Contribution to the solvation Free & -4.81 & -220.36 & -91.73 \\
5 & $\quad$ Energy (ESURF) & -68.43 & 191.82 & 68.57 \\
6 & $\Delta$ Ggas (VdW + EEL) & 40.99 & -28.53 & -23.16 \\
\hline 7 & $\Delta$ GSTOTAL (VdW + EEL + EGB + ESURF) & -27.44 & & \\
\hline
\end{tabular}

Apart from the analysis of the RMSD and RMSF curves, interaction's stability is also followed by energy complex calculations during dynamic molecular simulation, one of which is the Molecular Mechanics-Generalized Born Surface Area (MM-GBSA) method. This calculation method produces free energy $(\Delta \mathrm{G})$ ligand-receptor bonding systems in molecular dynamics simulations. When a compound has low free energy $(\Delta \mathrm{G})$ that means it has a better ability to bind to the receptor.

Based on Table 5, 1,4Naphthalenedione-2-ethyl-3-hydroxy - COX-2 compounds have lower total free energy ( $\triangle$ GTOTAL) values compared to JMS and paracetamol systems against the receptor. The Van der Waals (VdW) interactions, electrostatic energy (EEL), and non-polar solvation free energy contribute to the value of total bond free energy ( $\triangle$ GTOTAL) which affects the stability of the three sample compounds against COX-2. The large contribution of Van der Waals (VdW) interaction energy to the system indicates that the amino acid residues that make up the active sac of COX-2 protein are dominated by hydrophobic residues. The total value of free bonding energy $(\Delta G)$ in the 1,4Naphthalenedione-2-ethyl-3-hydroxy - COX-2 is lower $(-28,53 \mathrm{kcal} / \mathrm{mol})$ compared to $\mathrm{COX}$ 2 system of JMS (-27,44 kcal / mol ) and paracetamol $(-23,16 \mathrm{kcal} / \mathrm{mol})$. This showed that the affinity level of 1,4-Naphthalenedione2-ethyl-3-hydroxy against the receptor is predicted to be better and more potent as an antipyretic drug than the counterparts. 


\section{CONCLUSION}

Based on the screening results, molecular docking, and molecular dynamics, it is concludable that the 1,4-naphthalenedione2-ethyl-3-hydroxy have the ability to bind and stably interact with COX-2. It means that the active compound is potentially a strong candidate for antipyretics (COX-2 inhibitor).

\section{ACKNOWLEDGMENTS}

The authors are grateful to the Ministry of Research and Technology/BRIN Indonesia for the Penelitian Dosen Pemula (PDP) Grant 2020. The authors are also grateful to the Research in Molecular Biotechnology and Bioinformatics Laboratory of Padjadjaran University.

\section{REFERENCES}

Adriani. 2018. Prediksi senyawa bioaktif dari tanaman sanrego (Lunasia amara Blanco) sebagai inhibitor enzim siklooksigenase-2 (cox-2) melalui pendekatan Molecular Docking. Jurnal Ilmiah Pena. 10(1): 6-11.

Bassolé IHN, Juliani HR. 2012. Essential oils in combination and their antimicrobial properties. Molecules. 17(4): 3989-4006.

Bayala B, Bassole IHN, Scifo R, Gnoula C, Morel L, Lobaccaro JMA, Simpore J. 2014. Anticancer activity of essential oils and their chemical components - A review. American Journal of Cancer Research. 4(6): 591-607.

Filimonov D, Druzhilovskiy D, Lagunin A, Gloriozova T, Rudik A, Dmitriev A, Pogodin P, Poroikov V. 2018. Computeraided prediction of biological activity spectra for chemical compounds: opportunities and limitations. Biomedical Chemistry: Research and Methods.1(1): e00004.

https://doi.org/10.18097/bmcrm00004.

Gondokesumo, Evalina M, Sumitro SB, Handono $\mathrm{K}$, Pardjianto B, Widowati W, Utomo DH. 2020. A computational study to predict wound healing agents from the peel of the mangosteen (Garcinia mangostana L.) extract. International Journal Bioautomation. 24(3): 265-276.

Gunawan D, Mulyani S. 2004. Ilmu Obat Alam (Farmakognosi) Jilid I. Jakarta (ID): Penerbit Penebar Swadaya.
Harvey RA, Champe PC. 2013. Farmakologi Ulasan Bergambar, Edisi 4. Jakarta (ID): Kedokteran EGC.

Kilo AL, Aman, LO, Sabihi I, Kilo JLa. 2019. Study of potential of 1-N-Substituted pyrazoline analogues of thiosemicarbazones as antiamoebic agent using in silico screening. Indo. J. Chem. Res. 7(1): 9-24.

Liju VB, Jeena K, Kuttan R. 2011. An evaluation of antioxidant, anti-inflammatory, and antinociceptive activities of essential oil from Curcuma longa. L. Indian Journal of Pharmacology. 43(5): 526-531.

Mardianingrum R, Bachtiar KR, Nofriyaldi, Ali, Fadilah NN. 2019. Uji Antipiretik Minyak Atsiri Dan Ekstrak Metanol Rimpang Bangle (Zingiber Purpureum R) pada Mencit Jantan Galur Swiss Webster. Prosiding Seminar Nasional. ISBN: 978602-5793-65-3: 92-97.

Marwaha A, Goel RK, Mahajan MP. 2007. PASSpredicted design, synthesis and biological evaluation of cyclic nitrones as nootropics. Bioorganic \& Medicinal Chemistry Letters. 17(18): $5251-$ 5255. doi:10.1016/j.bmcl.2007.06.071.

Parikesit AA, Rizky N. 2020. drug repurposing option for COVID-19 with Structural Bioinformatics of Chemical Interactions Approach. Cermin Dunia Kedokteran. 47(3): 222-226.

Ruswanto R. 2015. molecular docking empat turunan isonicotinohydrazide pada mycobacterium tuberculosis enoyl-acyl carrier protein reductase (InhA). Jurnal Kesehatan Bakti Tunas Husada: Jurnal Ilmu-Ilmu Keperawatan, Analis Kesehatan Dan Farmasi. 13(1): 135-141.

Sipahelut SG. 2019. perbandingan komponen aktif minyak atsiri dari daging buah pala kering cabinet dryer melalui metode distilasi air dan air-uap. AGRITEKNO, Jurnal Teknologi Pertanian. 8(1): 8-13.

Syahputra G, Ambarsari L, Sumaryada T. 2014. simulasi docking kurkumin enol, bismetoksi kurkumin dan analognya sebagai inhibitor enzim12-lipoksigenase. Jurnal Biofisika. 10(1): 55-67.

Syamsi N, Andilolo A. 2019. Efek antipiretik ekstrak jeruk nipis (Fructus citrus Aurantifolium) pada mencit (Mus musculus). 
Healthy Tadulako Journal. 5(1): 52-57.

Wadood A, Ahmed N, Shah L, Ahmad A, Hassan H, Shams S. 2013. In-silico drug design: An approach which revolutionarised the drug discovery process. OA Drug Design and Delivery. 1(1): 1-4.
Wang Y, You CX, Yang K, Wu Y, Chen R, Zhang WJ, Liu ZL, Du SS, Deng ZW, Geng ZF, Han J. 2015. Bioactivity of essential oil of Zingiber purpureum rhizomes and its main compounds against two stored product insects. Journal of Economic Entomology. 108(3): 925-932. 